\title{
Anterioposterior distribution of $\mathrm{AT}_{1}$ angiotensin receptors in caudal brainstem cardiovascular regulatory centers of the rat
}

\author{
Erick A. Bourassa ${ }^{1,2}$, Alan F. Sved ${ }^{3}$, and Robert C. Speth ${ }^{1,4}$ \\ ${ }^{1}$ Department of Pharmacology, School of Pharmacy, University of Mississippi, University, MS \\ 38677 \\ 2 Biological Sciences, Northwest Missouri State University, Maryville, MO 64468 \\ 3 Department of Neuroscience, University of Pittsburgh, Pittsburgh, PA 15260 \\ ${ }^{4}$ Department of Pharmaceutical Sciences, College of Pharmacy, Nova Southeastern University, \\ Fort Lauderdale, FL 33328-2018
}

\begin{abstract}
Angiotensin II acts on Ang II type $1\left(\mathrm{AT}_{1}\right)$ receptors in areas of the caudal brainstem involved in cardiovascular regulation. In particular, activation of $\mathrm{AT}_{1}$ receptors in the rostral ventrolateral medulla (RVLM) has been suggested to contribute to hypertension. However, the characteristics of $\mathrm{AT}_{1}$ receptors in the RVLM of rat, the species in which the most experimental work has been done, is not well documented. This study evaluated $\mathrm{AT}_{1}$ receptor binding along a $2.7 \mathrm{~mm}$ length of rat medulla, which included the full extent of the RVLM and the caudal ventrolateral medulla (CVLM). Sections of medulla from female rats cut on a cryostat were incubated with five concentrations of ${ }^{125}$ I-sarcosine ${ }^{1}$, isoleucine ${ }^{8}$ angiotensin II to assess the density (Bmax) and dissociation constant $\left(\mathrm{K}_{\mathrm{D}}\right)$ of the receptors for the radioligand. The dorsomedial medulla (DMM) displayed a high density of $\mathrm{AT}_{1}$ binding $(1207 \pm 100 \mathrm{fmol} / \mathrm{g})$, which peaked at $0.4 \mathrm{~mm}$ rostral to the calamus scriptorius (approximately $14 \mathrm{~mm}$ caudal to Bregma). The RVLM and CVLM displayed significantly lower (p $<0.01$ ) densities of $\mathrm{AT}_{1}$ binding, $278 \pm 38$ and $379 \pm 64 \mathrm{fmol} / \mathrm{g}$, respectively. However, the dissociation constants were significantly lower (i.e., higher affinity) in RVLM and CVLM (164 \pm 38 and $178 \pm 27$ $\mathrm{pM}$, respectively, ) than in DMM $(328 \pm 12 \mathrm{pM}, \mathrm{p}<0.01$ and $\mathrm{p}<0.05$ respectively). These results provide an anatomical and pharmacological framework for future studies on the role in cardiovascular regulation of $\mathrm{AT}_{1}$ receptors in the caudal brainstem.
\end{abstract}

\section{Keywords}

rostral ventrolateral medulla (RVLM); caudal ventrolateral medulla (CVLM); Dorsomedial medulla; quantitative receptor autoradiography; Saturation binding assay; Maximum binding capacity (Bmax); Dissociation constant $\left(\mathrm{K}_{\mathrm{D}}\right)$

Correspondence: Robert C. Speth, Ph.D., Department of Pharmaceutical Sciences, Nova Southeastern University, Fort Lauderdale, FL 33328-2018, Telephone: 954-262-1330, Fax: 954-262-2278, rs1251@ nova.edu.

Publisher's Disclaimer: This is a PDF file of an unedited manuscript that has been accepted for publication. As a service to our customers we are providing this early version of the manuscript. The manuscript will undergo copyediting, typesetting, and review of the resulting proof before it is published in its final citable form. Please note that during the production process errors may be discovered which could affect the content, and all legal disclaimers that apply to the journal pertain. 


\section{Introduction}

Angiotensin II (Ang II), long known for its peripheral cardiovascular effects (Kaschina and Unger, 2003; Laragh et al., 1975), is now recognized as having significant effects on the cardiovascular system via its actions in the brain (Bourassa et al., 2008; Carlson and Wyss, 2008; McKinley et al., 2003; Phillips and de Oliveira, 2008; Sved et al., 2003; Veerasingham and Raizada, 2003). Within the caudal caudal brainstem, there is evidence that Ang II acts in the dorsomedial medulla (DMM, including the nucleus of the solitary tract (NTS) and area postrema), rostral ventrolateral medulla (RVLM), and caudal ventrolateral medulla (CVLM) to regulate the cardiovascular system. The area postrema is a circumventricular organ which is reported to be sensitive to blood-borne Ang II (Bishop and Hay, 1993; Joy and Lowe, 1970). In vitro studies have shown that area postrema neurons are responsive to Ang II (Consolimcolombo et al., 1996; Hay and Lindsley, 1995; Sun and Ferguson, 1996). Injection of Ang II into the NTS region of the DMM (Diz et al., 1997; Fow et al., 1994; Katsunuma et al., 2003; Tan et al., 2005) or the CVLM (Alzamora et al., 2006; Muratani et al., 1991) decreases blood pressure whereas injection of Ang II into the RVLM increases it (Allen et al., 1988; Andreatta et al., 1988). In each instance, this action of Ang II appears to be mediated by an action on the $\mathrm{AT}_{1}$ subtype of angiotensin receptors as $\mathrm{AT}_{1}$ selective blockade abolishes these responses (Averill et al., 1994; Fontes et al., 1997; Ito et al., 2002; Tagawa and Dampney, 1999).

The actions of Ang II on caudal brainstem $\mathrm{AT}_{1}$ receptors is receiving increasing attention because of the possibility that they are major contributors to hypertension. For example, in the spontaneously hypertensive rat (SHR) model of hypertension, Ang II injection into the RVLM increases blood pressure significantly more than in the Wistar Kyoto (WKY) strain. Also, $\mathrm{AT}_{1}$ receptor blockade in the RVLM produces a significant depressor response in the SHR, but fails to produce any significant effect in the WKY (Ito et al., 2002; Muratani et al., 1991). Similar responses are also seen in the Dahl-salt sensitive rat model of hypertension (Ito et al., 2003). This suggests that activation of ventrolateral brainstem $\mathrm{AT}_{1}$ receptors contributes to hypertension in these animal models, but in normotensive animals these $\mathrm{AT}_{1}$ receptors are not tonically activated under resting conditions. In line with this, it has been shown that expression of a constitutively active $\mathrm{AT}_{1 \mathrm{a}}$ receptor in the RVLM of normotensive WKY rats increased blood pressure significantly, whereas overexpression of the wild-type $\mathrm{AT}_{1 \mathrm{a}}$ receptor did not (Allen et al., 2006). Heightened responsiveness of the RVLM to Ang II can even be induced in normotensive animals with an elevated salt intake (Adams et al., 2008).

Despite this increasing interest in $\mathrm{AT}_{1}$ receptors in the ventrolateral medulla (VLM), these receptors have not been adequately characterized in this region of the rat brain. Indeed, whereas autoradiographic studies of Ang II binding have provided evidence of $\mathrm{AT}_{1}$ binding sites in the VLM, the specific localization to RVLM or CVLM has not been discriminated. Two studies have attempted to quantitate the $\mathrm{AT}_{1}$ receptor binding found in the VLM; one of these studies presents data in the VLM without clearly distinguishing between RVLM and CVLM, and in fact the figure presented appears to be in a transition zone between the two (Allen et al., 1987), while the other (Song et al., 1992) describes sampling as far dorsal as the NTS.

The existing studies of Ang II binding sites in the medulla have focused on the distribution of these sites, assuming similar binding characteristics among the different regions. However, this has left open the question of whether binding affinities are the same in these different regions. The purpose of this study was to determine the density of the $\mathrm{AT}_{1}$ receptors in the RVLM, CVLM, and DMM regions of the rat using quantitative densitometric receptor autoradiography with saturation isotherm analysis to determine receptor concentration (Bmax) and dissociation constant $\left(\mathrm{K}_{\mathrm{D}}\right)$ of the receptors. 


\section{Results}

\section{Saturation Receptor Autoradiography}

A major goal of the present study was to determine $B \max$ and $\mathrm{K}_{\mathrm{D}}$ of the $\mathrm{AT}_{1}$ receptor in the CVLM and RVLM of the rat caudal brainstem at different anteriorposterior coordinates with a concurrent comparison to the DMM (Figure 1). Specific $\mathrm{AT}_{1}$ binding was noted as a rostrocaudal column in the DMM region and in the VLM. $\mathrm{AT}_{1}$ Binding was also noted stretching between these two regions in the reticular formation as well as in the spinal trigeminal nucleus. For the DMM and VLM regions, at each coordinate noted, a saturation isotherm was constructed and Bmax and $\mathrm{K}_{\mathrm{D}}$ were derived. Figure 2 shows autoradiographic images of the ${ }^{125}$ I-SI Ang II saturation binding in the DMM and CVLM. Figure 3 shows autoradiographic images of ${ }^{125}$ I-SI Ang II saturation binding in the RVLM. Demonstrative saturation isotherms for the DMM, CVLM, and RVLM are shown in Figure 4. Figure 5 shows Bmax for each brain region along the anterioposterior axis.

In the DMM, the Bmax peaks approximately $0.4 \mathrm{~mm}$ rostral to calamus scriptorius (>1800 $\mathrm{fmol} / \mathrm{g}$ wet weight) before leveling off at approximately $1.4 \mathrm{~mm}$ rostral to calamus scriptorius to $\sim 750 \mathrm{fmol} / \mathrm{g}$ wet weight. In the VLM (both caudal and rostral), the Bmax is significantly lower ( $\mathrm{p}<0.001)$ than in the DMM averaging around $330 \mathrm{fmol} / \mathrm{g}$ wet weight. The $\mathrm{K}_{\mathrm{D}}$ did not vary along the anterioposterior axis in any of the brain regions studied (data not shown), however the $\mathrm{K}_{\mathrm{D}} \mathrm{s}$ of the CVLM and RVLM were significantly less than that of the DMM $(\mathrm{p}<0.01)$, but did not significantly differ from each other. Also, the Bmax did not differ significantly between the CVLM and the RVLM. Table 1 summarizes the Bmax and $\mathrm{K}_{\mathrm{D}}$ data for the three brain regions.

There was a substantial amount of ${ }^{125}$ I-SI Ang II binding in the cerebellum (Figures 2 and 3). However, most of this binding is not displaceable by $3 \mu \mathrm{M}$ Ang II (Panel F of Figures 2 and 3 ) and it was not evaluated in this study.

\section{Discussion}

This is the first study utilizing receptor binding autoradiography to fully characterize $\mathrm{AT}_{1}$ receptor binding in the regions of the rat medulla that are critically involved in cardiovascular regulation. The key findings of this study are: (1) In addition to the previously characterized $\mathrm{AT}_{1}$ receptor binding in the $\mathrm{DMM}, \mathrm{AT}_{1}$ receptor binding is clearly present in the rat ventrolateral medulla, extending throughout the CVLM and RVLM in the rostral-caudal plane; (2) the density of $\mathrm{AT}_{1}$ receptor binding is lower in CVLM and RVLM than in DMM; (3) the $\mathrm{K}_{\mathrm{D}}$ of $\mathrm{AT}_{1}$ binding sites is lower (i.e., higher affinity) in the ventrolateral medulla than in the DMM. Each of these issues, along with their potential physiological significance, will be discussed in turn.

\subsection{Localization of $\mathrm{AT}_{\mathbf{1}}$ binding in the rat medulla}

The presence of $\mathrm{AT}_{1}$ receptors in all three of the major components of the DMM surveyed, area postrema, NTS and dorsal motor nucleus of the vagus, is well documented in previous studies (Gehlert et al., 1986; Mendelsohn et al., 1984). All three of these nuclei have cardiovascular significance: the area postrema as a sensor of blood-borne angiotensins (Joy and Lowe, 1970), the NTS as the site of termination of baroreceptor afferents (Jordan and Spyer, 1977), and the dorsal motor nucleus of the vagus as a site of preganglionic parasympathetic neurons (Taylor, 1994).

$\mathrm{AT}_{1}$ receptor binding in the RVLM region has been reported in other species (Allen et al., 1988; Mendelsohn et al., 1988; Moulik et al., 2002) and quantified in a single prior study in rat (Allen et al., 1987). However, the characterization of these receptors throughout the rostral- 
caudal extent of the CVLM and RVLM has not previously been reported. Based on the prior demonstration that pharmacological stimulation of $\mathrm{AT}_{1}$ receptors in the RVLM increases blood pressure (Alzamora et al., 2006; Andreatta et al., 1988; Ito et al., 2002; Sasaki and Dampney, 1990) the activity of RVLM sympathoexcitatory neurons (Allen et al., 1988; Averill et al., 1994), and neuronal excitation in vitro ( $\mathrm{Li}$ and Guyenet, 1995), it is clear that functional $\mathrm{AT}_{1}$ receptors exist in the RVLM. Similarly, the decrease in blood pressure produced by stimulation of $\mathrm{AT}_{1}$ receptors in the CVLM provided evidence for the presence of $\mathrm{AT}_{1}$ receptors in the CVLM (Alzamora et al., 2006; Muratani et al., 1991). Based on the present data, it is clear that $\mathrm{AT}_{1}$ binding sites have a considerable rostral-caudal distribution in the ventrolateral medulla.

Although the rat has been the species most studied for the functional effects of Ang II actions in the VLM, previous receptor binding studies have not supported a robust presence of these receptors in rat VLM. Autoradiographic studies in rabbits (Mendelsohn et al., 1988; Moulik et al., 2002), sheep and humans (Allen et al., 1987) have shown that $\mathrm{AT}_{1}$ binding in the VLM is nearly as robust as in DMM. While this is not the case in the rat, the $\mathrm{AT}_{1}$ binding is still demonstrable. Immunocytochemical studies of the rat (Hu et al., 2002; Wang et al., 2008) have also suggested the presence of $\mathrm{AT}_{1}$ receptors in RVLM, but these studies are problematic for several reasons. Most importantly, the $\mathrm{AT}_{1}$ receptor antibodies utilized in those studies may not be specific to $\mathrm{AT}_{1}$ receptors, e.g. immunostaining is abundant in the inferior olivary nucleus (Hu et al., 2002) which is reported to contain only $\mathrm{AT}_{2}$ receptors (Rowe et al., 1990). Also, Western blots of immunoreactive protein isolated from kidneys of $\mathrm{AT}_{1 \mathrm{a}}{ }^{-/-}$mouse kidneys labeled with the antibody used by Hu et al., 2002 show identical labeling as the wild type mouse kidneys (Adams et al., 2008).

Studies using in situ hybridization histochemistry have failed to detect any significant level of $\mathrm{AT}_{1}$ receptor mRNA expression in the RVLM of the adult rat (Bunnemann et al., 1992; Lenkei et al., 1998). However, the presence of $\mathrm{AT}_{1}$ receptor mRNA in RVLM using polymerase chain reaction amplification has been reported (Adams et al., 2008; Chan et al., 2007), though the amount of $\mathrm{AT}_{1}$ receptor mRNA in the RVLM relative to other brain regions was not specified. The apparent paucity of $\mathrm{AT}_{1}$ receptor mRNA in RVLM suggests that $\mathrm{AT}_{1}$ receptors in this region may be on afferent nerve terminals. However, electrophysiological studies of RVLM neurons provides strong evidence that they are present on nerve cell bodies ( $\mathrm{Li}$ and Guyenet, 1995). In addition, electron microscopic analysis of $\mathrm{AT}_{1}$ receptor immunoreactivity indicates that the $\mathrm{AT}_{1}$ receptors are present on dendrites of the RVLM neurons (Wang et al., 2008). Thus the question of cellular localization of $\mathrm{AT}_{1}$ receptors in the $\mathrm{RVLM}$ remains unresolved.

$\mathrm{AT}_{1}$ binding is present in the rostrocaudal region of the VLM, generally acknowledged to be the pressor region of the RVLM, containing spinally projecting sympathoexcitatory neurons. The sampling area used to determine $\mathrm{AT}_{1}$ binding in the RVLM encompasses the stereotaxic coordinates described for pressor sites responsive to Ang II and glutamate (Averill et al., 1994; Willette et al., 1983). The RVLM extends caudally from the caudal tip of the facial nucleus for several hundred micrometers and lies along its ventral surface. The location of $\mathrm{AT}_{1}$ binding maps well to this location (Figure 1: Panels E and F, and Figure 5). While the area with $\mathrm{AT}_{1}$ receptor binding appears to fit well with the rostrocaudal extent of the RVLM, the lateral boundaries of the $\mathrm{AT}_{1}$ receptor binding domain of the RVLM extends beyond the region where pressor responses are elicited.

The CVLM is a region that is functionally and anatomically distinct from the RVLM. Stimulation of the CVLM produces a depressor response, mediated by an inhibitory projection from CVLM to RVLM (Guyenet, 2006). $\mathrm{AT}_{1}$ receptor binding localizes to the same region of the CVLM as the depressor response that can be elicited from this region and the area containing neurons that are activated by decreased arterial pressure (Alzamora et al., 2006; Muratani et 
al., 1991). The density of $\mathrm{AT}_{1}$ receptor binding is rather constant along the rostral-caudal extent of this ventrolateral medullary column. However, along this column, the effect of stimulating these receptors on cardiovascular regulation is divergent. With a virtual absence of information on what controls the level of stimulation of these receptors along the extent of this column, it is difficult to try to put this into a physiological framework. Within the RVLM, the angiotensinergic input to the $\mathrm{AT}_{1}$ receptors seems to arise from the hypothalamus (Ito et al., 2002; Sved et al., 2003; Tagawa and Dampney, 1999). This input is involved in osmotically driven increases in sympathetic outflow (Freeman and Brooks, 2007), and may be involved in hypertension (Allen, 2002; Ito et al., 2002). However, there are unresolved questions regarding the existence of angiotensinergic neurons, so other sources of angiotensinergic input, e.g., extracellularly synthesized Ang II, must be considered. Similar types of studies have not examined the source of angiotensinergic influence on the CVLM. In addition to $\mathrm{AT}_{1}$ binding being present in the DMM and VLM, binding was also observed in the reticular region between the DMM and VLM (Figures 1, 2, and 3), though with a lower density than observed even in VLM. While this pattern of localization is observed for many substances, its significance is still unclear.

\section{2 $\mathrm{AT}_{1}$ receptor binding has different $\mathrm{K}_{\mathrm{D}}$ in DMM and VLM}

The present studies utilizing I ${ }^{125}$ SI-Ang II binding show a $\mathrm{K}_{\mathrm{D}}$ of $\mathrm{AT}_{1}$ receptors in the DMM of approximately $325 \mathrm{pM}$. This number is in reasonably good agreement with other data for $\mathrm{AT}_{1}$ receptors in brain (Rowe et al., 1992), and the saturation isotherms indicate a single high affinity site in this region. The $\mathrm{K}_{\mathrm{D}}$ measured in the ventrolateral medulla, approximately 175 $\mathrm{pM}$, is still in the range of values reported in the literature, but is significantly lower than the $\mathrm{K}_{\mathrm{D}}$ that was measured in the DMM at the same time (Table 1). This lower $\mathrm{K}_{\mathrm{D}}$ suggests that neurons in the RVLM and CVLM are more sensitive to Ang II and that smaller amounts of Ang II are needed to activate these receptors. This difference in affinity presumably reflects differences in post-translational modification of the receptor or differential interaction with the membranes or protein components of the $\mathrm{AT}_{1}$ receptor-containing cells in the VLM. Whatever the explanation, it highlights potentially important differences in $\mathrm{AT}_{1}$ receptors in different brain regions.

\subsection{Summary and Conclusions}

The present study documents the distribution of $\mathrm{AT}_{1}$ receptor binding sites in the in rat medulla. $\mathrm{AT}_{1}$ receptors are present throughout the ventrolateral brainstem as well as in the DMM. While the density of $\mathrm{AT}_{1}$ binding sites is lower in the VLM than in the DMM, the affinity of these binding sites is greater. These observations provide anatomical information supporting the physiological role(s) of Ang II in these caudal brainstem regions in cardiovascular regulation.

\section{Experimental Procedure}

\subsection{Subjects}

Adult female retired breeder (250-300 g) Wistar rats (Harlan) were housed under standard condition with ad lib access to food and water. Rats were killed by decapitation and their brains were rapidly removed and frozen. Four adult female rats in metestrus or diestrus determined by daily microscopic evaluation of smears of vaginal epithelial cells (Long and Evans, 1922) were used for the rostrocaudal saturation binding assay. Brainstems and cerebella were serial sectioned (sets of six) with a cryostat at a thickness of 20 microns and thaw-mounted onto gelatin-coated microscope slides. The slides were air dried and kept frozen at $-20^{\circ} \mathrm{C}$ until used for autoradiography. The protocol for these studies was approved by the University of Mississippi IACUC. All possible efforts were made to minimize pain and discomfort to the experimental animals. 


\subsection{Receptor Autoradiography}

Saturation angiotensin receptor autoradiography was performed essentially as previously described (Rowe et al., 1992). Briefly, slides were pre-incubated in $150 \mathrm{mM} \mathrm{NaCl}, 5 \mathrm{mM}$ EDTA, $0.1 \mathrm{mM}$ bacitracin, and $50 \mathrm{mM}$ sodium phosphate buffer at $\mathrm{pH}$ 7.1-7.2 (AM5 buffer) for 30 minutes at room temperature. Five of the slides from each set were then incubated in AM5 buffer containing a concentration of ${ }^{125}$ I-SI Ang II ranging from $80 \mathrm{pM}$ to $1900 \mathrm{pM}$ in the presence of $10 \mu \mathrm{M}$ PD123319 (a selective non-peptide $\mathrm{AT}_{2}$ receptor antagonist) for 120 minutes. Under these conditions, all specific ${ }^{125}$ I-SI Ang II binding is at the $\mathrm{AT}_{1}$ receptor (Karamyan et al., 2009). The sixth slide from each set was incubated with $1900 \mathrm{pM}^{125} \mathrm{I}-\mathrm{SI}$ Ang II in the presence of an $\mathrm{AT}_{1}$ receptor saturating concentration $(3 \mu \mathrm{M})$ of Ang II for 120 minutes to determine non-specific binding of ${ }^{125} \mathrm{I}$-SI Ang II. All slides were rinsed in two changes of distilled water, five changes of AM5 buffer for one minute each, and then two additional changes of distilled water. Slides were then dried under a stream of cool air, taped to cardboard, and exposed to autoradiographic film (Kodak Biomax MR-1) for either 3 (for DMM region analyses) or 10 days (for VLM analyses) at $-20^{\circ} \mathrm{C}$. A set of ${ }^{125}$ I calibration standards (Microscales RPA-522, Amersham) were included with each film for densitometric quantitation.

Specific binding of ${ }^{125}$ I-SI Ang II was quantitated essentially as previously described (Rowe et al., 1992). Briefly, images of the autoradiograms were analyzed using AIS 6.0 software (Interfocus Imaging, Linton, Cambridge England). Because the cerebella contained a large amount of non-specific ${ }^{125}$ I-SI Ang II binding that made it difficult to focus on the binding that was present in the caudal brainstem, only the ${ }^{125}$ I-SI Ang II binding in the caudal brainstem is shown in the saturation autoradiograms portrayed in this manuscript. The ${ }^{125} \mathrm{I}$ calibration standards included on the autoradiograms were used to construct a standard curve relating optometric density to ${ }^{125}$ I concentration, allowing quantitation of ${ }^{125}$ I-SI Ang II binding to brain regions of interest. Non-specific binding for each of the five concentrations of ${ }^{125} \mathrm{I}$-SI Ang II was calculated by interpolation of a two-point linear plot of the non-specific value at $1900 \mathrm{pM}{ }^{125}$ I-SI Ang II and the origin. The calculated non-specific binding for each concentration of ${ }^{125}$ I-SI Ang II was then subtracted from the total binding values to derive specific binding. A thresholding technique was used during data acquisition. For the DMM, thresholding was necessary to exclude data from low-binding areas near the NTS region (see Figure 1). However, this study used multiple concentrations of ${ }^{125}$ I-SI Ang II and thus each concentration of ${ }^{125}$ I-SI Ang II required a different threshold. The level of thresholding for each concentration of ${ }^{125}$ I-SI Ang II in the DMM was determined by choosing one level of the DMM to measure ( $\sim 0.8 \mathrm{~mm}$ rostral to calamus scriptorius), setting the threshold for one concentration of ${ }^{125}$ I-SI Ang II, and measuring the "proportional area" captured (the proportion of pixels exceeding threshold versus the total number of pixels within the area measured). The threshold was then set for other concentrations of ${ }^{125}$ I-SI Ang II (from adjacent sections) at the threshold level that produced the same "proportional area" as the first section measured. These threshold levels were then kept constant for all DMM measurements on that particular film. The same thresholding technique was used during the data acquisition for the CVLM and RVLM as well, except that the threshold was always set to zero (all pixels that measured below $0 \mathrm{fmol} / \mathrm{g}$ of binding were excluded). See Figure 1 for details.

The anteroposterior (AP) coordinates for the measurement of the RVLM were $2.3 \mathrm{~mm}$ rostral to $1.0 \mathrm{~mm}$ rostral to the calamus scriptorius ( 12.1 to $13.4 \mathrm{~mm}$ caudal to Bregma) measured at 120 micron intervals. The approximate area measured as the RVLM was an elliptical area $0.7 \mathrm{~mm}^{2}$ in size (long axis $\sim 1.3 \mathrm{~mm}$, short axis $\sim 0.7 \mathrm{~mm}$ ), centered $2.40 \mathrm{~mm}$ lateral to the midline and $0.42 \mathrm{~mm}$ dorsal from the ventral surface (see Figure 1: Panels $\mathrm{E}$ and $\mathrm{F}$ for the placement of this sample region); the size and location of this ellipse was derived from the profile of the $\mathrm{AT}_{1}$ binding. 
The anterioposterior coordinates for the measurement of the CVLM were $0.9 \mathrm{~mm}$ to $0.2 \mathrm{~mm}$ rostral to the calamus scriptorius ( $~ 13.5$ to $14.2 \mathrm{~mm}$ caudal to Bregma) measured at 120 micron intervals. The approximate area measured as CVLM was a circular area $0.28 \mathrm{~mm}^{2}$ in size $(0.6$ $\mathrm{mm}$ in diameter) centered $2.05 \mathrm{~mm}$ lateral to the midline and $0.90 \mathrm{~mm}$ dorsal from the ventral surface. The anterioposterior coordinates for measurement of the DMM were $2.3 \mathrm{~mm}$ rostral to $0.4 \mathrm{~mm}$ caudal to the calamus scriptorius ( 12.1 to $14.8 \mathrm{~mm}$ caudal to Bregma). The areas sampled as RVLM and CVLM encompassed the region identified as RVL (rostroventrolateral reticular nucleus) and CVL (caudoventrolateral reticular nucleus) which overlap with the areas labeled as C1 and A1 in the brain atlases of Paxinos and Watson (Paxinos and Watson, 1986; Paxinos and Watson, 2005). However, the definition of calamus scriptorius in this manuscript differs from that of Paxinos and Watson (Paxinos and Watson, 1986; Paxinos and Watson, 2005) who refer to the calamus scriptorius as obex. See Figure 1 for details.

\subsection{Kinetic and Statistical Calculations}

Bmax and $\mathrm{K}_{\mathrm{D}}$ for ${ }^{125} \mathrm{I}$-SI Ang II was determined as $\mathrm{B}=\mathrm{Bmax} * \mathrm{~L} /\left(\mathrm{L}+\mathrm{K}_{\mathrm{D}}\right)$ by non-linear regression analysis (Prism, Graphpad Softward, San Diego, CA) where L= free concentration of ${ }^{125}$ I-SI Ang II and B is specific binding expressed as fmol/g wet weight of tissue.

All results are expressed as a mean \pm standard error of the mean. One way Analysis of Variance (ANOVA) followed by Bonferroni post-hoc tests were used to compare values in the DMM, RVLM, and CVLM for the saturation receptor autoradiography data.

\section{Acknowledgments}

Supported by NIH grants HL-55786 and HL-076312, and The Peptide Radioiodination Service Center of the University of Mississippi.

\section{Comprehensive List of Abbreviations}

$\begin{array}{ll}{ }^{125} \text { I-SI Ang II } & { }^{125} \text { I-sarcosine }^{1} \text {,isoleucine } \\ \text { Ang II } & \text { Angiotensin II } \\ \text { AT }_{1} & \text { Angiotensin II } \\ \text { Bmax } & \text { Receptor concentration } \\ \text { CVLM } & \text { Caudal ventrolateral medulla } \\ \text { DMM } & \text { Dorsomedial medulla } \\ \text { KD } & \text { Dissociation constant } \\ \text { MnA } & \text { Median accessory nucleus of the medulla } \\ \text { NTS } & \text { Solitary tract nucleus } \\ \text { RVLM } & \text { Rostral ventrolateral medulla } \\ \text { SHR } & \text { Spontaneously hypertensive rat } \\ \text { VLM } & \text { Ventrolateral medulla } \\ \text { WKY } & \text { Wistar-Kyoto }\end{array}$

\section{References}

Adams JM, McCarthy JJ, Stocker SD. Excess Dietary Salt Alters Angiotensinergic Regulation of Neurons in the Rostral Ventrolateral Medulla. Hypertension 2008;52:932-937. [PubMed: 18779436] 
Allen AM. Inhibition of the hypothalamic paraventricular nucleus in spontaneously hypertensive rats dramatically reduces sympathetic vasomotor tone. Hypertension 2002;39:275-280. [PubMed: 11847197]

Allen AM, Chai SY, Sexton PM, Lewis SJ, Verberne AJ, Jarrott B, Louis WJ, Clevers J, McKinley MJ, Paxinos G. Angiotensin II receptors and angiotensin converting enzyme in the medulla oblongata. Hypertension 1987;9:III198-III205. [PubMed: 3036704]

Allen AM, Dampney RA, Mendelsohn FA. Angiotensin receptor binding and pressor effects in cat subretrofacial nucleus. Am J Physiol 1988;255:H1011-H1017. [PubMed: 2903678]

Allen AM, Dosanjh JK, Erac M, Dassanayake S, Hannan RD, Thomas WG. Expression of constitutively active angiotensin receptors in the rostral ventrolateral medulla increases blood pressure. Hypertension 2006;47:1054-1061. [PubMed: 16618838]

Alzamora AC, Santos RA, Campagnole-Santos MJ. Baroreflex modulation by angiotensins at the rat rostral and caudal ventrolateral medulla. Am J Physiol Regul Integr Comp Physiol 2006;290:R1027R1034. [PubMed: 16306161]

Andreatta SH, Averill DB, Santos RA, Ferrario CM. The ventrolateral medulla. A new site of action of the renin-angiotensin system. Hypertension 1988;11:I163-I166. [PubMed: 2831146]

Averill DB, Tsuchihashi T, Khosla MC, Ferrario CM. Losartan, nonpeptide angiotensin II-type 1 (AT1) receptor antagonist, attenuates pressor and sympathoexcitatory responses evoked by angiotensin II and L-glutamate in rostral ventrolateral medulla. Brain Res 1994;665:245-252. [PubMed: 7895060]

Bishop VS, Hay M. Involvement of the area postrema in the regulation of sympathetic outflow to the cardiovascular system. Front Neuroendocrinol 1993;14:57-75. [PubMed: 8486207]

Bourassa EA, Sved AF, Speth RC. Angiotensin modulation of rostral ventrolateral medulla (RVLM) in cardiovascular regulation. Mol Cell Endocrinol. 2008

Bunnemann B, Iwai N, Metzger R, Fuxe K, Inagami T, Ganten D. The distribution of angiotensin II $\mathrm{AT}_{1}$ receptor subtype mRNA in the rat brain. Neurosci Lett 1992;142:155-158. [PubMed: 1280791]

Carlson SH, Wyss JM. Neurohormonal regulation of the sympathetic nervous system: new insights into central mechanisms of action. Curr Hypertens Rep 2008;10:233-240. [PubMed: 18765096]

Chan SH, Wang LL, Tseng HL, Chan JY. Upregulation of AT1 receptor gene on activation of protein kinase Cbeta/nicotinamide adenine dinucleotide diphosphate oxidase/ERK1/2/c-fos signaling cascade mediates long-term pressor effect of angiotensin II in rostral ventrolateral medulla. J Hypertens 2007;25:1845-1861. [PubMed: 17762649]

Consolimcolombo FM, Hay M, Smith TC, Elizondofournier M, Bishop VS. Subcellular mechanisms of angiotensin II and arginine vasopressin activation of area postrema neurons. Amer J Physiol-Regul Integr C 1996;40:R34-R41.

Diz DI, Fantz DL, Benter IF, Bosch SM. Acute depressor actions of angiotensin II in the nucleus of the solitary tract are mediated by substance P. Amer. J Physiol Regul Integr C 1997;42:R28-R34.

Fontes MA, Martins Pinge MC, Naves V, Campagnole-Santos MJ, Lopes OU, Khosla MC, Santos RA. Cardiovascular effects produced by microinjection of angiotensins and angiotensin antagonists into the ventrolateral medulla of freely moving rats. Brain Res 1997;750:305-310. [PubMed: 9098557]

Fow JE, Averill DB, Barnes KL. Mechanisms of angiotensin-induced hypotension and bradycardia in the medial solitary tract nucleus. Am J Physiol 1994;267:H259-H266. [PubMed: 7914065]

Freeman KL, Brooks VL. AT(1) and glutamatergic receptors in paraventricular nucleus support blood pressure during water deprivation. Am J Physiol Regul Integr Comp Physiol 2007;292:R1675R1682. [PubMed: 17185407]

Gehlert DR, Speth RC, Wamsley JK. Distribution of [125I]angiotensin II binding sites in the rat brain: a quantitative autoradiographic study. Neuroscience 1986;18:837-856. [PubMed: 3762929]

Guyenet PG. The sympathetic control of blood pressure. Nat Rev Neurosci 2006;7:335-346. [PubMed: 16760914]

Hay M, Lindsley KA. Membrane properties of area postrema neurons. Brain Res 1995;705:199-208. [PubMed: 8821750]

Hu L, Zhu DN, Yu Z, Wang JQ, Sun ZJ, Yao T. Expression of angiotensin II type 1 (AT(1)) receptor in the rostral ventrolateral medulla in rats. J Appl Physiol 2002;92:2153-2161. [PubMed: 11960969] 
Ito S, Hiratsuka M, Komatsu K, Tsukamoto K, Kanmatsuse K, Sved AF. Ventrolateral medulla AT1 receptors support arterial pressure in Dahl salt-sensitive rats. Hypertension 2003;41:744-750. [PubMed: 12623990]

Ito S, Komatsu K, Tsukamoto K, Kanmatsuse K, Sved AF. Ventrolateral medulla AT1 receptors support blood pressure in hypertensive rats. Hypertension 2002;40:552-559. [PubMed: 12364362]

Jordan D, Spyer KM. Studies on the termination of sinus nerve afferents. Pflugers Arch 1977;369:6573. [PubMed: 560010]

Joy MD, Lowe RD. Evidence that the area postrema mediates the central cardiovascular response to angiotensin II. Nature 1970;228:1303-1304. [PubMed: 4321187]

Karamyan VT, Gadepalli R, Rimoldi J, Speth R. Brain AT1 angiotensin receptor subtype binding: Importance of peptidase inhibition for identification of angiotensin II as an endogenous ligand. J Pharmacol Exp Ther. 2009

Kaschina E, Unger T. Angiotensin AT1/AT2 receptors: regulation, signalling and function. Blood Press 2003;12:70-88. [PubMed: 12797627]

Katsunuma N, Tsukamoto K, Ito S, Kanmatsuse K. Enhanced angiotensin-mediated responses in the nucleus tractus solitarii of spontaneously hypertensive rats. Brain Res Bull 2003;60:209-214. [PubMed: 12754082]

Laragh JH, Sealey JE, Buhler FR, Vaughan ED, Brunner HR, Gavras H, Baer L. The renin axis and vasoconstriction volume analysis for understanding and treating renovascular and renal hypertension. Am J Med 1975;58:4-13. [PubMed: 234677]

Lenkei Z, Palkovits M, Corvol P, Llorens-Cortes C. Distribution of angiotensin TYPE-I receptor messenger RNA expression in the adult rat brain. Neuroscience 1998;82:827-841. [PubMed: 9483539]

Li YW, Guyenet PG. Neuronal excitation by angiotensin II in the rostral ventrolateral medulla of the rat in vitro. Am J Physiol 1995;268:R272-R277. [PubMed: 7840331]

Long, JA.; Evans, HM. The oestrous cycle in the rat and its associated phenomena. Univ. California Press; Berkeley, CA: 1922.

McKinley MJ, Albiston AL, Allen AM, Mathai ML, May CN, McAllen RM, Oldfield BJ, Mendelsohn FA, Chai SY. The brain renin-angiotensin system: location and physiological roles. Int J Biochem Cell Biol 2003;35:901-918. [PubMed: 12676175]

Mendelsohn FA, Allen AM, Clevers J, Denton DA, Tarjan E, McKinley MJ. Localization of angiotensin II receptor binding in rabbit brain by in vitro autoradiography. J Comp Neurol 1988;270:372-384. [PubMed: 3372742]

Mendelsohn FAO, Quirion R, Saavedra JM, Aguilera G, Catt KJ. Autoradiographic localization of angiotensin II receptors in rat brain. Proc Natl Acad Sci USA 1984;81:1575-1579. [PubMed: 6324205]

Moulik S, Speth RC, Turner BB, Rowe BP. Angiotensin II receptor subtype distribution in the rabbit brain. Exp Brain Res 2002;142:275-283. [PubMed: 11807581]

Muratani H, Averill DB, Ferrario CM. Effect of angiotensin II in ventrolateral medulla of spontaneously hypertensive rats. Am J Physiol 1991;260:R977-R984. [PubMed: 1674644]

Paxinos, G.; Watson, C. The Rat Brain in Stereotaxic Coordinates. Academic Press; Orlando: 1986.

Paxinos, G.; Watson, C. The Rat Brain in Stereotaxic Coordinates - The New Coronal Set. Academic Press; Orlando: 2005.

Phillips MI, de Oliveira EM. Brain renin angiotensin in disease. J Mol Med 2008;86:715-722. [PubMed: 18385968]

Rowe BP, Grove KL, Saylor DL, Speth RC. Angiotensin II receptor subtypes in the rat brain. Eur J Pharmacol 1990;186:339-342. [PubMed: 2289535]

Rowe BP, Saylor DL, Speth RC. Analysis of angiotensin II receptor subtypes in individual rat brain nuclei. Neuroendocrinology 1992;55:563-573. [PubMed: 1584339]

Sasaki S, Dampney RA. Tonic cardiovascular effects of angiotensin II in the ventrolateral medulla. Hypertension 1990;15:274-283. [PubMed: 2303285]

Song K, Allen AM, Paxinos G, Mendelsohn FAO. Mapping of angiotensin II receptor subtype heterogeneity in rat brain. J Comp Neurol 1992;316:467-484. [PubMed: 1577995] 
Sun KQ, Ferguson AV. Angiotensin II and glutamate influence area postrema neurons in rat brain slices. Regul Pept 1996;63:91-98. [PubMed: 8837216]

Sved AF, Ito S, Sved JC. Brainstem mechanisms of hypertension: role of the rostral ventrolateral medulla. Curr Hypertens Rep 2003;5:262-268. [PubMed: 12724060]

Tagawa T, Dampney RA. AT(1) receptors mediate excitatory inputs to rostral ventrolateral medulla pressor neurons from hypothalamus. Hypertension 1999;34:1301-1307. [PubMed: 10601134]

Tan PS, Potas JR, Killinger S, Horiuchi J, Goodchild AK, Pilowsky PM, Dampney RA. Angiotensin II evokes hypotension and renal sympathoinhibition from a highly restricted region in the nucleus tractus solitarii. Brain Res 2005;1036:70-76. [PubMed: 15725403]

Taylor EW. The evolution of efferent vagal control of the heart in vertebrates. Cardioscience 1994;5:173182. [PubMed: 7827254]

Veerasingham SJ, Raizada MK. Brain renin-angiotensin system dysfunction in hypertension: recent advances and perspectives. Br J Pharmacol 2003;139:191-202. [PubMed: 12770924]

Wang G, Milner TA, Speth RC, Gore AC, Wu D, Iadecola C, Pierce JP. Sex differences in angiotensin signaling in bulbospinal neurons in the rat rostral ventrolateral medulla. Am J Physiol Regul Integr Comp Physiol 2008;295:R1149-R1157. [PubMed: 18685065]

Willette RN, Barcas PP, Krieger AJ, Sapru HN. Vasopressor and depressor areas in the rat medulla. Identification by microinjection of L-glutamate. Neuropharmacology 1983;22:1071-1079.

[PubMed: 6138727] 


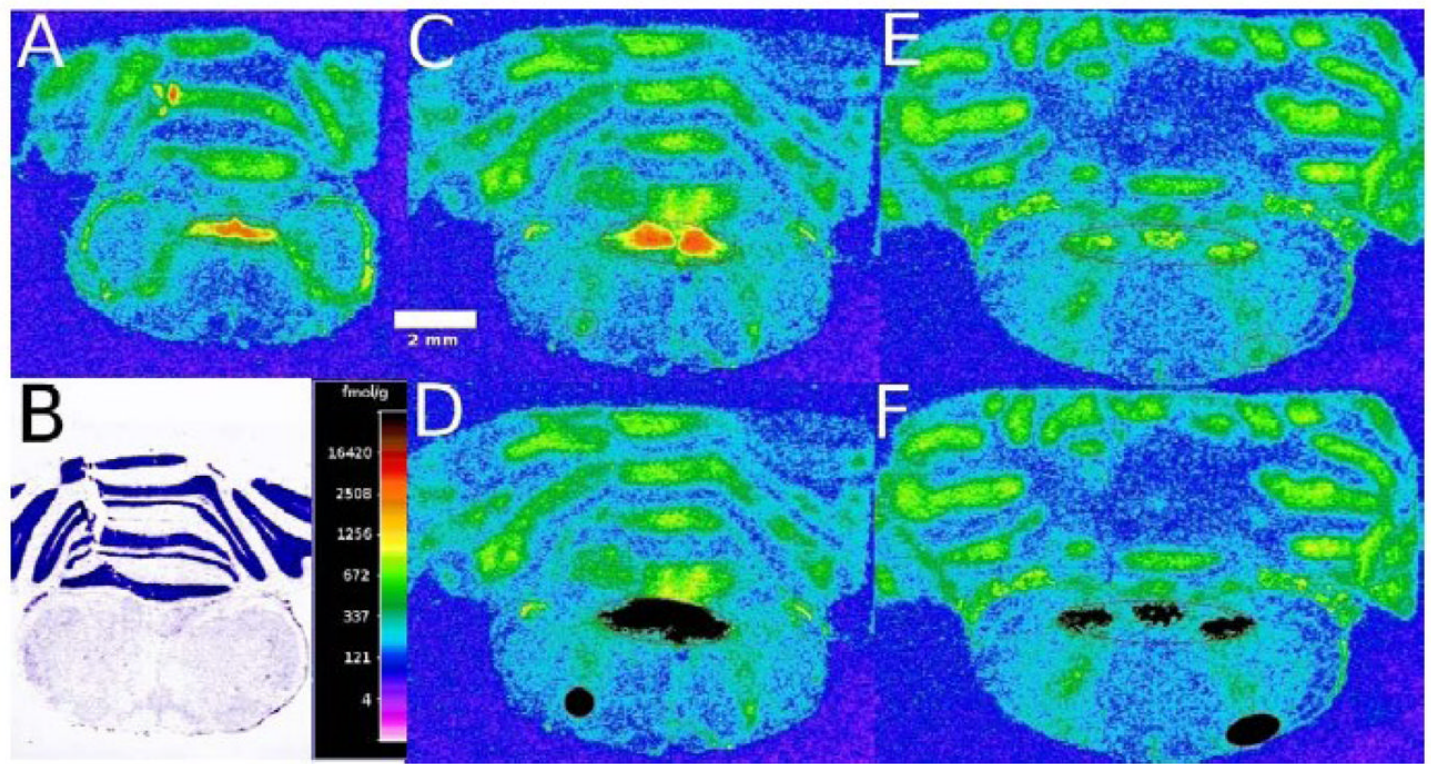

Figure 1. Sampling Regions and Thresholding of MnA, DMM, CVLM, and RVLM

Representative autoradiograms with circles showing sampling regions (top panels) and pixels sampled after thresholding (Panels D and E). Sections shown are at the level of the median accessory nucleus (MnA) approximately $0.35 \mathrm{~mm}$ caudal to the calamus scriptorius (Panel A), medial DMM and CVLM approximately $0.8 \mathrm{~mm}$ rostral to the calamus scriptorius (Panels C and D), and rostral DMM and RVLM approximately $1.8 \mathrm{~mm}$ rostral to the calamus scriptorius (Panels E and F). Panel B shows the caudal brainstem section adjacent to Panel A after thionin staining. 


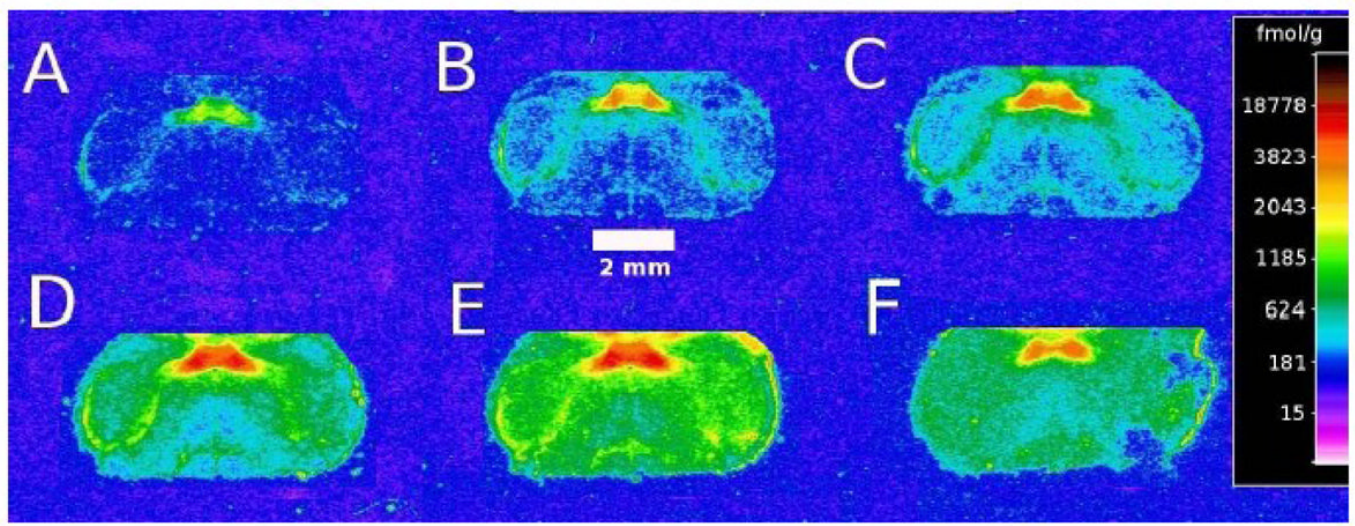

Figure 2. DMM and CVLM Saturation Binding Autoradiogram

Representative autoradiographic images of the caudal brainstem of the rat at approximately $0.3 \mathrm{~mm}$ rostral to calamus scriptorius (cerebellum digitally removed from images because the high non-specific binding distracts from the caudal brainstem areas of study). Panels A through $\mathrm{E}$ show $\mathrm{AT}_{1}$ binding at sequentially increasing concentrations of ${ }^{125}$ I-SI Ang II ranging from $80-1900$ pM. Panel F shows non-specific binding (1900 pM ${ }^{125}$ I-SI Ang II in the presence of $3 \mu \mathrm{M}$ Ang II). 


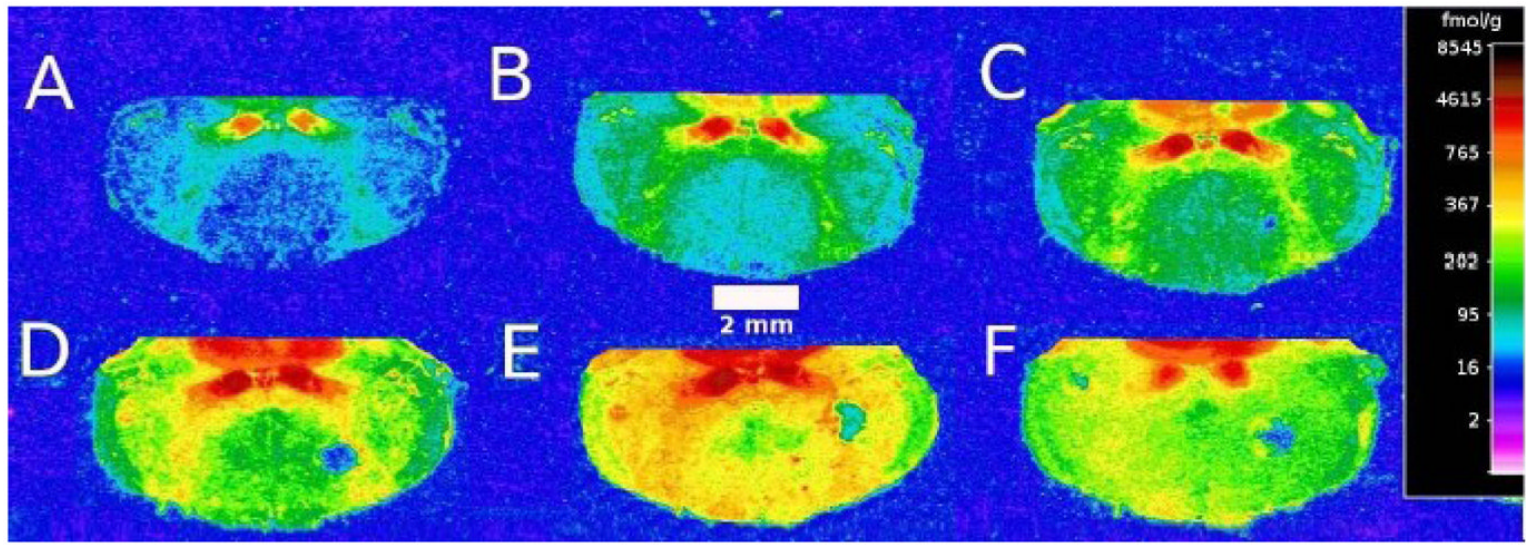

Figure 3. RVLM Saturation Binding Autoradiogram

Representative autoradiographic images of the caudal brainstem of the rat at approximately $1.1 \mathrm{~mm}$ rostral to calamus scriptorius (cerebellum digitally removed from images because the high non-specific binding distracts from the caudal brainstem areas of study). Panels A through E show $\mathrm{AT}_{1}$ binding at sequentially increasing concentrations of ${ }^{125}$ I-SI Ang II ranging from $80-1900 \mathrm{nM}$. Panel F shows non-specific binding (1900 nM ${ }^{125}$ I-SI Ang II in the presence of $3 \mu \mathrm{M}$ Ang II). 
A

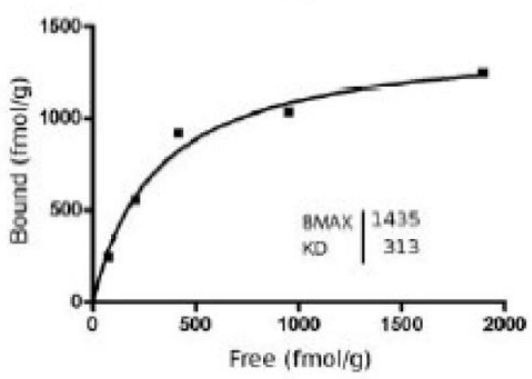

B

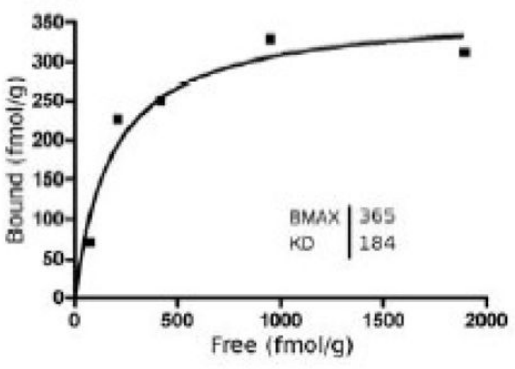

C

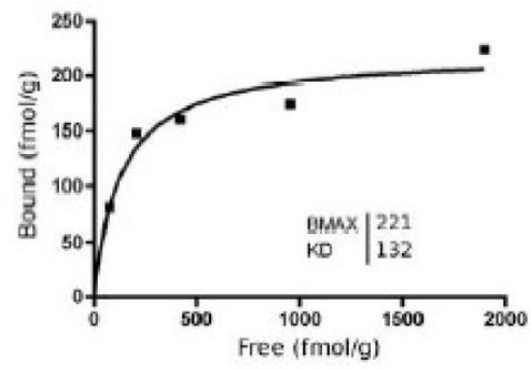

Figure 4. DMM, CVLM, and RVLM Saturation Isotherms

Demonstrative saturation isotherms for the DMM (panel A, $0.1 \mathrm{~mm}$ caudal to calamus scriptorius), CVLM (panel B, 0.2 mm rostral to calamus scriptorius), and RVLM (panel C, 1.0 $\mathrm{mm}$ rostral to calamus scriptorius). Note that the ordinates are not drawn to the same scale. 


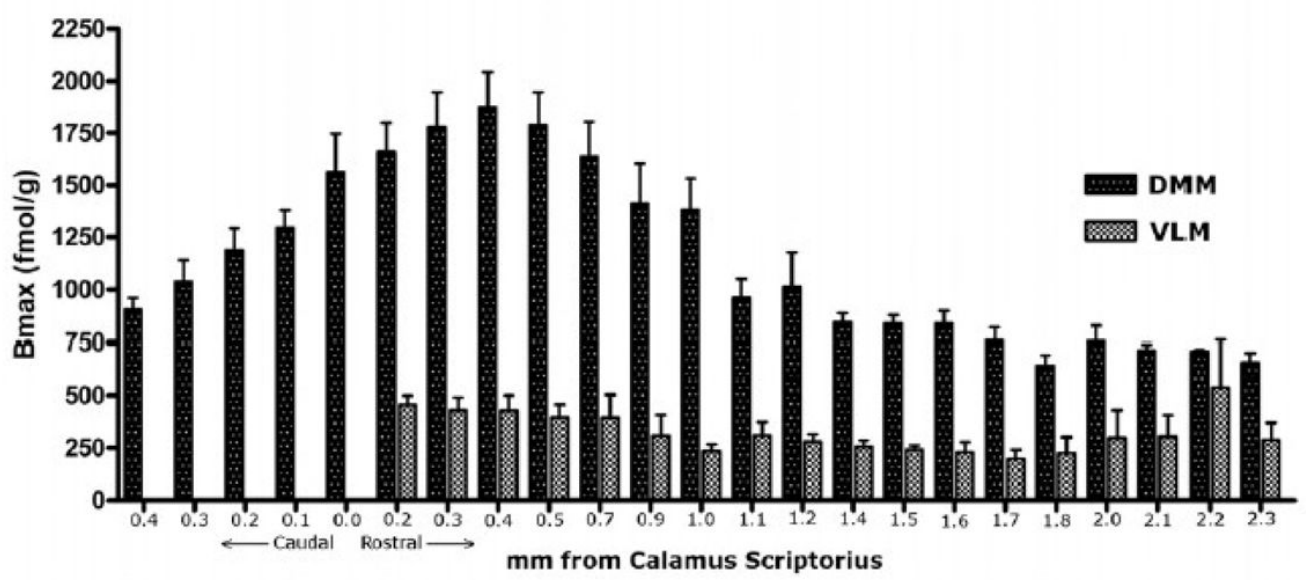

Figure 5. AT 1 Receptor Bmax in DMM and VLM

Bmax along the anterioposterior axis for DMM and VLM (caudal and rostral). Note that the CVLM runs between 0.2 and $0.8 \mathrm{~mm}$ rostral to calamus scriptorius and the RVLM runs between 1.0 and $2.4 \mathrm{~mm}$ rostral to calamus scriptorius. Values presented are mean $\pm \mathrm{SEM}, \mathrm{n}=4$. 


\section{Table 1}

Bmax (fmol/g) and $K_{D}(\mathrm{pM})$ values (mean +/- SEM, $\mathrm{n}=4$ ) for DMM, CVLM, and RVLM. $\mathrm{t}$ values are for post hoc Bonferroni comparisons.

\begin{tabular}{ccccc}
\hline & Bmax & Significance vs DMM & $\mathbf{K}_{\mathbf{D}}$ & Significance vs DMM \\
DMM & $1207+/-100$ & & $328+/-12$ & \\
CVLM & $379+/-64$ & $\mathrm{t}=8.14, \mathrm{p}<0.001$ & $178+/-27$ & $\mathrm{t}=3.82, \mathrm{p}<0.05$ \\
RVLM & $278+/-38$ & $\mathrm{t}=9.13, \mathrm{p}<0.001$ & $164+/-38$ & $\mathrm{t}=4.17, \mathrm{p}<0.01$ \\
\hline
\end{tabular}

